Derecho internacional 



\section{El derecho internacional general en la jurisprudencia del Tribunal Constitucional peruano. Las normas de ius cogens}

\section{Carolina Loayza Tamayo}

No es función del jurista simplemente tomar nota de lo que hacen los Estados, particularmente los más poderosos, que no dudan en buscar fórmulas para imponer su "voluntad", inclusive en relación con el trato a ser dispensado a las personas bajo su jurisdicción. La función del jurista es mostrar y decir cuál es el Derecho.

Antonio Cançado Trindade Voto concurrente, Corte IDH O C18

\section{Introducción}

El derecho internacional contemporáneo establece derechos y obligaciones para garantizar la convivencia pacífica entre los sujetos del derecho internacional, principalmente de los Estados, $y$, al igual que cualquier otro ordenamiento jurídico, está conformado por normas jurídicas ${ }^{1}$, principios e instituciones. El desarrollo del derecho internacional en el siglo $\mathrm{XX}$, nos ha permitido visualizar que este ordenamiento jurídico está integrado por diversos tipos de normas ${ }^{2}$. El profesor Bodansky sugiere siete criterios para identificar otras tantas dimensiones de las normas internacionales, partiendo de una concepción del derecho inter-

1 Antonio Remiro Brotons define al derecho internacional como "el conjunto de normas jurídicas que, en un momento dado, regulan las relaciones (derechos y obligaciones) de los miembros de la sociedad internacional a los que se reconoce subjetividad en este orden". Remiro Brotons et al. (2007, p. 45).

2 Citado por García San José (2008, pp. 107-108). 
nacional como "espacio normativo multidimensional". En primer lugar, si la norma es producto de un proceso intencionado y reflexivo o es generada de manera más orgánica o espontánea - normas convencionales y normas consuetudinarias, respectivamente-. En segundo lugar, el número de participantes en la formulación de la norma - bilaterales, trilaterales, multilaterales, etc. - . En tercer lugar, si la autoridad de una norma requiere el consentimiento estatal - acuerdos en forma simplificada, tratados-. En cuarto lugar, si una norma es de naturaleza constitutiva o reguladora, es decir, si confiere un permiso o establece una prohibición o un requerimiento. En quinto lugar, si la norma emplea un lenguaje mandatorio o exhortativo. En sexto lugar, si la norma es específica o general, precisa o, por el contrario, vaga en su alcance. En séptimo lugar, si una norma lleva asociado o no algún mecanismo de implementación y, en tal caso, cuál es la naturaleza y alcance de este.

A la tradicional clasificación de normas escritas - convencionales- y normas no escritas - consuetudinarias-, locales, regionales y con vocación universal, en función de su ámbito espacial de aplicación, se pueden identificar normas que responden a las nuevas características del derecho internacional, así como a su relación con el derecho interno de los Estados a efectos de su eficacia: normas operativas - caracterizadas por su aplicación directa por sus destinatarios - y programáticas - normas que requieren un desarrollo legislativo para su aplicación -3 ; normas de hard law y de soft law - las primeras, también llamadas de lege lata, crean obligaciones jurídicas, vinculantes, exigibles, como los tratados", y "se caracterizan por su eficacia vinculante" (Universidad de Cádiz, s. f.); las de soft law o non binding norms (concepto que es atribuido al internacio-

3 Debemos precisar que la naturaleza programática de la norma internacional no afecta la obligatoriedad y exigibilidad de esta, no pudiendo los Estados alegar la falta de implementación de las normas programáticas en los casos de incumplimiento de las obligaciones derivadas de dichas normas, para evadir su responsabilidad internacional.

4 Los tratados obligan a los Estados que hayan manifestado en el ámbito internacional su consentimiento, en obligarse por los mismos a través de la ratificación, la adhesión, la aceptación o la aprobación (artículo 2 de la Convención de Viena de 1969 sobre el Derecho de los Tratados). García San José (2008, p. 108) refiere que la norma de hard law "no siempre va revestid[a] con la forma de un tratado, pudiendo derivar de otros instrumentos en principio no legalmente vinculantes, como las Declaraciones de Organizaciones Internacionales". No compartimos la posición de García San José de considerar como hard law a instrumentos de las 
nalista lord Mc Fair, quien lo utilizaba como sinónimo de lege ferenda [Becerra, 2005, p. 571]) se definen como normas internacionales inciertas, bien en razón de su contenido, bien en razón de su inclusión en una fuente del derecho internacional no susceptible de crear obligaciones jurídicas (Sánchez, 2004, p. 142). En tanto lege ferenda, estas normas formarían parte del desarrollo progresivo del derecho internacional, es decir, del proceso de creación de las normas consuetudinarias.

Otra clasificación de las normas internacionales incluye a las dispositivas $^{5}$ - respecto de las cuales los Estados pueden pactar libremente- y las imperativas o normas de ius cogens - respecto de las cuales los Estados no pueden pactar (Carrillo Salcedo, 1976, pp. 253 y 258)-. Estas últimas nos llevan a la conclusión de que el derecho internacional no se reduce a ser un producto del consentimiento estatal, pues esto no es ilimitado, en tanto "los conceptos abstractos de libertad y de soberanía absoluta de los Estados son incompatibles con la existencia misma de una sociedad internacional" 6 . El concepto, naturaleza y efectos del ius cogens han sido desarrollados por la doctrina y la jurisprudencia internacionales. García San José postula una emergente legalidad internacional de base consensual a partir del interés general, que supera el tradi-

organizaciones internacionales en general, salvo que se trate de las resoluciones del Consejo de Seguridad o de organizaciones supranacionales, por ejemplo, cuya fuerza vinculante deriva de sus respectivos tratados constitutivos. Sin embargo, sí consideramos dentro de las normas de hard law a las normas consuetudinarias que pueden estar contenidas o declaradas en instrumentos en principio no legalmente vinculantes: las Declaraciones de Organizaciones Internacionales.

5 José Acosta Estévez, profesor de Derecho Internacional Público y de Relaciones Internacionales de la Universidad de Girona, España, señala que la esencia de las normas dispositivas "radica en la facultad que concede el ordenamiento positivo a los sujetos para que puedan modificar, por obra de su voluntad, en el seno de sus relaciones mutuas el alcance de la regulación dispuesta por el derecho" (1995, pp. 3-22).

6 Acosta Estévez (1995, pp. 3-22). Como bien señala Sánchez Flores (2004, p. 138), ello sin perjuicio de que el consentimiento del Estado desempeña en el derecho internacional una función de capital importancia en el proceso de formación de las normas jurídicas, coincidiendo con Rodríguez Carrión (2009, p. 143) en que "el consentimiento del Estado es el punto inicial y necesario del proceso de creación de normas, pero no es su término final; aunque el consentimiento individual del Estado es relevante, no es definitivo: para la creación de la norma jurídica internacional es preciso que el consentimiento de cada Estado cristalice en el consentimiento del grupo social de Estados (consenso o consensus común)". 
cional principio del respeto del consentimiento del Estado que responde al interés común, y que solo sería respuesta del derecho internacional a las "nuevas exigencias que afectan a la comunidad internacional de Estados en su conjunto y no solo al conjunto de Estados de la comunidad internacional" (2008, p. 129), que posibilita la emergencia de una opinio iuris antes que la práctica estatal. Esta normativa tiene naturaleza consuetudinaria. Como bien señala el profesor Antonio Cançado Trindade, "[c]on la consagración del ius cogens en el derecho internacional convencional, específicamente en las dos Convenciones de Viena sobre el Derecho de los Tratados (1969 y 1986), el próximo paso consistió en determinar su incidencia más allá del derecho de los tratados" (Corte IDH, 17 de setiembre de 2003, párr. 67), es decir, en el derecho internacional general, en donde se ubica su espacio natural de producción (Corte IDH, 17 de setiembre de 2003, párr. 68). Siendo el ius cogens, como señala el profesor Antonio Cançado Trindade, "una categoría abierta, que se expande en la medida en que se despierta la conciencia jurídica universal (fuente material de todo el derecho) para la necesidad de proteger los derechos inherentes a todo ser humano en toda y cualquier situación" (Corte IDH, 17 de setiembre de 2003, párr. 68), dicha expansión no podría excluir a los ordenamientos internos de los Estados, en donde podemos ya verificar su presencia e influencia (Alarcón García, 2010, p. 9).

En esta línea, en los últimos años se ha podido constatar que el Tribunal Constitucional peruano (TC) ha venido incorporando en la fundamentación de sus sentencias algunas de estas normas, v.g., normas de ius cogens o soft law ${ }^{7}$, acorde con esta tendencia de limitación del voluntarismo estatal. En líneas siguientes, analizaremos algunas sentencias del TC, que incorpora en su argumentación a las normas de ius cogens, así como en los votos singulares o razonados de sus magistrados, y trataremos de establecer su impacto e incidencia en el sistema jurídico de fuentes peruano.

Respecto al ius cogens, analizaremos dos de las sentencias del TC relacionadas con la obligación de prevención y sanción de las graves violaciones a los derechos humanos, tanto en tiempo de paz como de conflicto armado, y que califiquen como delitos internacionales contra los derechos humanos y el derecho internacional humanitario, que incorporan en su análisis argumentativo las normas de ius cogens, a fin de establecer su impacto e incidencia en el sistema jurídico de fuentes peruano.

7 El estudio del impacto de las normas de soft law en las sentencias del Tribunal Constitucional peruano será objeto de otro trabajo. 
A los efectos del análisis que nos proponemos, nos referiremos en primer término a las relaciones entre el derecho internacional y los derechos estatales, para luego determinar conceptualmente a las normas de ius cogens. Luego revisaremos la jurisprudencia del TC y terminaremos con nuestras conclusiones.

\section{La relación entre el derecho internacional y el derecho estatal}

El estudio de la relación entre el derecho internacional y el derecho interno resulta de importancia fundamental, en razón de que la eficacia y la efectividad de las normas de derecho internacional en el ámbito interno de los Estados dependerán, en gran medida, de la manera en que esos ordenamientos se conformen a las normas internacionales y les den efecto.

Respecto a la relación entre el derecho interno de los Estados y el derecho internacional público, tradicionalmente la doctrina internacional ha abordado el problema de las relaciones entre ambos órdenes jurídicos desde un punto de vista de la existencia o inexistencia de subordinación de un ordenamiento con respecto al otro (Diez de Velasco, 1996, pp. 211 ss.), y, dependiendo de ello, de si la norma de derecho internacional se incorpora o no automáticamente al derecho interno de los Estados (Jiménez de Aréchaga, 1962, pp. 1 ss.). Se trata de una visión que podemos llamar "desde afuera" de los derechos internos, la que ha tratado de mostrar las diversas posiciones de la doctrina internacional, que considera además la jurisprudencia internacional y, por tanto, va a diferir de la perspectiva constitucional, que más bien parte de un examen que vamos a calificar "desde adentro" del ordenamiento jurídico interno para, a través de la interpretación doctrinaria o jurisprudencial del derecho interno, proyectarse hacia el derecho internacional (Loayza Tamayo, 2007, pp. 107-154). La importancia de este estudio se relaciona con la eficacia del derecho internacional, pues el cumplimiento de sus normas depende de los derechos internos de los Estados ${ }^{8}$.

8 A propósito de la terminología usada por la autora, "visión desde afuera", es decir desde el derecho internacional, y "visión desde adentro", es decir desde el derecho constitucional, Piza Escalante utiliza los términos ordenamientos hacia afuera y ordenamiento hacia adentro de un modo distinto, para indicar cómo el panorama internacional muestra tradicionalmente al derecho internacional y al derecho interno, que en la actualidad "se han venido confundiendo, al extremo 
La primera visión de la relación derecho internacional - derecho nacional nos lleva a analizar las teorías clásicas dualista ${ }^{9}$ y monista ${ }^{10}$. La primera concibe al derecho interno y al derecho internacional como dos órdenes jurídicos diferentes, separados e independientes entre sí, porque regulan relaciones diversas y tienen un origen distinto; en tal sentido, las normas del derecho internacional serían irrelevantes en los ordenamientos jurídicos internos, necesitando, para su aplicación interna, de un acto especial de "recepción" que transforme la norma internacional en norma de derecho interno. Así, la teoría dualista postula la existencia de dos ordenamientos jurídicos separados, que no entran, en principio, en relación. Por su parte, la tesis monista sostiene que se trata de un solo derecho, en el que coexisten dos subsistema jurídicos válidos simultáneamente; y si el derecho internacional y el nacional se suponen válidos simultáneamente, entonces resulta inevitable una construcción monista"; en ese sentido, "forman una unidad". Sin embargo, esta unidad se genera no en cuanto a sus contenidos, sino en razón de la validez simultánea de ambos ordenamientos jurídicos, lo que lleva a la cuestión de su relación jerárquica ${ }^{11}$.

La práctica internacional demuestra que el derecho internacional no toma partido por ninguna de las teorías y deja la cuestión a los derechos internos; sin embargo, en caso de conflicto, el derecho internacional prevalece sobre los derechos internos, según ha establecido la jurisprudencia internacional ${ }^{12}$. En consecuencia, cualquier norma

de converger, si es que no de coincidir, en las mismas materias, obligando de este modo a los juristas a encontrar soluciones nuevas a las antinomias que esta concurrencia provoca inevitablemente; al punto de que hoy el ordenamiento interno no se puede desentender más de las exigencias del internacional". Véase Piza Escalante (1998, p. 183).

9 Los máximos exponentes de la tesis dualista fueron dos representantes del positivismo jurídico: Heinrich Triepel y Dionisio Anzilotti.

10 Hans Kelsen, fundador de la teoría monista.

11 Kelsen (1965a, pp. 204-220) y Kelsen (1965b, pp. 359-376). Según la concepción normativista de Kelsen, las normas jurídicas derivan su validez y fuerza obligatoria de otras normas superiores desde el punto de vista jerárquico hasta llegar a la norma fundamental o grundnorm. Si bien Kelsen sostuvo en 1926 que la norma fundamental podía ser ubicada bien en el derecho interno o bien en el derecho internacional, posteriormente entendió que se debía insertar en el derecho internacional.

12 Los casos son citados por diversos autores: Barberis (1973); Camargo (1983, p. 149); De la Guardia \& Delpech (1970, pp. 286-287); Diez de Velasco (1976); Gonzales 
interna que se oponga a una norma internacional debe considerársela sin efecto jurídico ${ }^{13}$.

La jurisprudencia arbitral internacional ha establecido que un Estado no puede invocar contra otro su propia Constitución con miras a evadir obligaciones que le incumben por el derecho internacional ${ }^{14}$. En el mismo sentido, la jurisprudencia de la Corte Permanente de Justicia Internacional estableció que un Estado no puede apoyarse en su propia legislación - incluso, invocar respecto a otro su propia Constituciónpara limitar el alcance de sus obligaciones internacionales o sustraerse a las obligaciones que le impone el derecho internacional ${ }^{15}$. El sustento de esta posición es que "las leyes nacionales son simples hechos, mani-

Campos (1983); Llanos Mansilla (1990, pp. 447-448); Miaja de la Muela (setiembre-diciembre de 1974, pp. 1001 ss.); Monroy Cabra (1978, pp. 94-95); Novak (julio-diciembre de 1994, pp. 77-78); Pastor Ridruejo (1962, pp. 25-28); Verdross (1978, p. 66). “Es un principio generalmente aceptado de derecho internacional que en las relaciones entre las potencias que son parte de un tratado, las normas de derecho interno no pueden prevalecer sobre las establecidas en el tratado". En Cuestión sobre las Comunidades Greco Búlgaras, CPJI. Serie B, núm. 17. Citado por Camargo (1983, p. 149); Pastor Ridruejo (1962, pp. 25-28).

13 Véase Piérola Balta \& Loayza (1994, p. 45). En la sentencia en el asunto Groenlandia, la Corte Permanente de Justicia Internacional declaró inválido un acto del Estado, contrario al derecho internacional. En CPJI, Series A/B. Núm. 53, pp. 56-71. Véase Monroy Cabra (1978, p. 95).

14 En la sentencia arbitral en el asunto Montijo (26 de julio de 1875), así como en la sentencia arbitral en el asunto G. Pinson (19 de octubre de 1928), citados por De la Guardia \& Delpech (1970, p. 287). Véase también Monroy Cabra (1978, p. 94).

15 Sentencia en el asunto de las Zonas Francas de la Alta y del País de Gex, entre Francia y Suiza. CPJI, Ser. A/B, No. 46, 167. “En consecuencia, cuando un representante que según el derecho internacional sea competente para comprometer al Estado exprese por algunos de los procedimientos establecidos el consentimiento del Estado en obligarse por un tratado, ha de considerarse en el derecho internacional que el Estado queda obligado por el tratado. Conforme a esa opinión, el incumplimiento de los requisitos internos puede entrañar la invalidez del tratado como legislación interna y hacer que al representante se le apliquen las disposiciones del derecho interno como consecuencia de sus actos, pero no menoscaba la validez del tratado en derecho internacional siempre que el representante haya actuado dentro de sus facultades dentro del derecho internacional". En De la Guardia \& Delpech (1970, p. 284). Véase también Camargo (1983, p. 149); Monroy Cabra (1978, p. 95). CPJI. Ser. A/B, No. 44, 24. Véase Pastor Ridruejo (1962, pp. 25-28). 
festaciones de voluntad y de la actividad del Estado, al igual que las decisiones judiciales o las medidas administrativas" 16 .

La jurisprudencia de la Corte Interamericana de Derechos Humanos se pronuncia a favor de la primacía del derecho internacional respecto al derecho interno de los Estados y los efectos de la incompatibilidad de la norma interna con la Convención Americana sobre Derechos Humanos y su consecuencia: la responsabilidad internacional del Estado y la falta de efectos jurídicos de la norma estatal frente a la norma internacional.

Para la Corte Interamericana,

Según el derecho internacional, las obligaciones que éste impone deben ser cumplidas de buena fe y no puede invocarse para su incumplimiento el derecho interno. Estas reglas pueden ser consideradas como principios generales del derecho y han sido aplicadas, aun tratándose de disposiciones de carácter constitucional, por la Corte Permanente de Justicia Internacional y la Corte Internacional de Justicia (Caso de las Comunidades Greco-Búlgaras (1930), Serie B, N. 17, pág. 32.; Caso de Nacionales Polacos de Dantzig (1931), Series A/B, N. ${ }^{\circ} 4$, 24; Caso de las Zonas Libres (1932), Series A/B, N. ${ }^{\circ} 46$, pág. 167 y Aplicabilidad de la Obligación de arbitrar bajo el Convenio de Sede de las Naciones Unidas (Caso de la Misión de la PLO) (1988 12, a 31-2, párr. 47). Asimismo estas reglas han sido codificadas en los artículos 26 y 27 de la Convención de Viena sobre el Derecho de los Tratados de $1969^{17}$.

Así, en el caso "Barrios Altos" (Chumbipoma Aguirre y otros), la Corte estableció ${ }^{18}$ :

44. Como consecuencia de la manifiesta incompatibilidad entre las leyes de autoamnistía y la Convención Americana sobre Derechos Humanos, las mencionadas leyes carecen de efectos jurídicos y no pueden seguir representando un obstáculo para la investigación de los hechos que constituyen este caso ni para la identificación y el castigo de los responsables, ni pueden tener igual o similar impacto

16 CPJI, Serie A, núm. 7, p. 22. mayo 14, 1926. Véase Camargo (1983, p. 149); Llanos Mansilla (1990, p. 4478). Esta posición de la CPJI fue confirmada por la CIJ, sentencia de 1955, pp. 35, 36, 51.

17 Corte IDH. Opinión Consultiva OC-14 de 9 de diciembre de 1994, párr. 31.

18 Corte IDH. Sentencia del 14 de marzo de 2001. 
respecto de otros casos de violación de los derechos consagrados en la Convención Americana acontecidos en el Perú.

$\mathrm{Y}$, en su parte resolutiva:

4. Declarar que las leyes de amnistía N 26479 y N 26492 son incompatibles con la Convención Americana sobre Derechos Humanos y, en consecuencia, carecen de efectos jurídicos.

Las teorías tradicionales vienen dando paso a una tercera teoría, mixta o de coordinación, que comprende elementos de las tesis dualista y monista, que concibe las relaciones de ambos derechos -internacional e interno - no como de confrontación, sino de cooperación y de complementación, aplicándose la norma que mejor proteja a la persona humana (Novak \& Salmón, 2000, p. 104). En ese sentido, el derecho internacional y el derecho interno no estarían en una relación de subordinación, pero sí de coordinación jerárquica, bajo un orden jurídico común, que sería el derecho natural (Novak, 2000, p. 549), importando lograr una solución razonable, de acuerdo con las circunstancias, en cada caso de conflicto entre la norma internacional y la de derecho interno. De acuerdo con el entonces juez de la Corte Interamericana de Derechos Humanos, Antonio Cançado Trindade, esta posición mixta conduce a considerar el conflicto entre los tratados internacionales y las leyes nacionales no desde una perspectiva exclusivamente positivista o normativa, sino desde una perspectiva que podría calificarse de funcional, de acuerdo con la cual se haga prevalecer la norma que con mayor legitimidad resuelva el hecho que se debe normar, es decir, la protección y el desarrollo de la persona humana ${ }^{19}$. Una aplicación de esta posición se encuentra en la sentencia del TC, en la que este, refiriéndose a la vinculatoriedad de las sentencias de los tribunales internacionales de derechos humanos cuya competencia ha sido aceptada por el Estado peruano, señala:

15. Lo expuesto, desde luego, no alude a una relación de jerarquización formalizada entre los tribunales internacionales de derechos humanos y los tribunales internos, sino a una relación de cooperación en la interpretación pro homine de los derechos fundamentales ${ }^{20}$ (énfasis agregado).

19 Cançado Trindade (2001, p. 267 ss.). Véase también Medina (1996, pp. 76-77).

20 Tribunal Constitucional del Perú. Caso Arturo Castillo Chirinos, expediente 2730-2006-PA/TC, emitido el 21 de julio de 2006, párrs. 12-15. 
Otro ejemplo de la postura mixta asumida por el TC - aunque la amplía a la protección al Estado, postura que no compartimos- lo encontramos en la sentencia que dictó en el hábeas corpus presentado a favor de José Santiago Bryson de la Barra y otros, presuntos autores de los hechos ocurridos en el establecimiento penal San Juan Bautista (El Frontón) el 19 de junio de 1986, en contra de la resolución expedida en mayoría por la Segunda Sala Especializada en lo Penal para Procesos con Reos Libres de la Corte Superior de Justicia de Lima, de fecha 29 de octubre de 2010, que declaró infundada la demanda de hábeas corpus, para que se declare nulo el auto de apertura de instrucción emitido por el juez del Cuarto Juzgado Penal Supraprovincial, con fecha 9 de enero de 2009 (expediente 2007-00213-0-1801-JR-PE-04) ${ }^{21}$.

El TC, si bien reconoce que los tratados ratificados forman parte del derecho nacional y debe respetar la jurisprudencia de los tribunales internacionales cuya competencia ha aceptado, considera que estas fuentes del derecho internacional no pueden interpretarse de modo que causen agravio a los individuos - justiciables:

17. Esto quiere decir que si bien el Perú es Estado parte del ámbito aplicativo de los tratados sobre derechos humanos que hubiera celebrado o ratificado, sometido a la competencia contenciosa de la Corte Interamericana de Derechos Humanos, así como respetuoso de los criterios jurisprudenciales establecidos por la Corte, sin embargo, ello no implica que se interprete las normas del derecho internacional (ius cogens) de manera arbitraria e irrazonable en agravio de los justiciables o del propio Estado, tanto más si se advierte que no hay ley o dispositivo legal de derecho interno que sancione la inaplicación de la prescripción de la acción penal o de la pena para los delitos contra la humanidad.

18. En este orden de ideas, tenemos que de lo reconocido en el artículo $44^{\circ}$ de nuestra Constitución se desprende la garantía de la plena vigencia de los derechos humanos, que a su vez implica el deber de protegerlos adoptando las medidas pertinentes a fin de su efectividad y de su tutela, reconocimiento que es conforme a las disposiciones de la Convención Americana sobre Derechos Humanos (artículo 1. ${ }^{\circ}$, inciso I) y el Pacto Internacional de Derechos Civiles y Políticos (artículo 2. ${ }^{\circ}$, inciso 2). Este deber involucra también a los juzgadores, sin que ello implique que con el pretexto de la eficacia de dicha garantía se pueda

21 Tribunal Constitucional del Perú. Expediente 01969-2011-PHC/TC LIMA, sentencia de 14 de junio de 2013. 
hacer interpretaciones extravagantes o caprichosas con un único objetivo, el poder punitivo del Estado. $Y$ es que, en cuanto materia penal constituye la controversia, de por medio se encuentra una gama de principios y normas que tutelan el derecho a la libertad individual del justiciable, por lo que el deber proteccionista del Estado es relativo en tanto el delito que persigue ya ha sido consumado (v.gr., los delitos instantáneos, como sucede con el ilícito de homicidio calificado) y no debe entenderse y menos interpretarse a la plena vigencia de los derechos humanos con el único afán retributivo del Estado cuyo fin es la sanción penal. Así por ejemplo, agraviar los derechos fundamentales de los justiciables a partir de la aplicación de ciertos dispositivos establecidos en los tratados respecto a una contingencia anterior a la fecha de su entrada en vigor en el Estado parte o, lo que es lo mismo, la aplicación de criterios jurisprudenciales sustentados en las normas de un tratado cuyo vigor es posterior a los hechos, transgrede el principio de irretroactividad de la ley y el de la aplicación de los tratados que establece la Constitución en sus artículos $103 .^{\circ}$ y $55 .^{\circ}$, puesto que conforme a lo allí establecido los tratados son derecho interno a partir de la fecha en la que entran en vigor y no deben ser aplicados retroactivamente, menos aún de manera desfavorable al reo.

A ello se debe agregar que resulta ilegal forzar figuras punitivas no vigentes al momento de los hechos criminosos, ya que aun cuando las conductas de los justiciables puedan ser asimiladas respecto de crímenes vigentes en el ordenamiento internacional, previamente debe observarse de manera ineludible las disposiciones que los propios tratados guardan de su aplicación en el tiempo y lo previsto en los artículos $55 .^{\circ}$ y $2 .^{\circ}$, inciso 24 , literal " $\mathrm{d}$ ”, de la Constitución peruana. Y es que si bien en los casos penales están inmersos derechos fundamentales que deben ser reconocidos tanto al inculpado corno a la parte agraviada, también lo es que en el caso de autos son los inculpados del caso penal por los que se ha recurrido en vía del hábeas corpus a pedir tutela de su derecho a la libertad individual; dicho de otro modo, es en referencia a los beneficiarios de autos que debe reconocerse o no la vulneración del derecho a la motivación resolutoria, conexo con el derecho a la libertad personal ${ }^{22}$ (énfasis agregado).

22 La autora deja constancia de que no comparte la lógica argumentativa del TC, el que no distingue los alcances de una norma internacional convencional de los de una norma internacional consuetudinaria, como es una norma de ius cogens. 
La visión o examen "desde adentro" de las relaciones entre el derecho internacional y los derechos internos nos conduce a estudiar la perspectiva constitucional sobre el tema, es decir, cómo se integra o recibe la norma internacional - convencional y/o consuetudinaria - en el ordenamiento jurídico interno y su valor una vez integrada como fuente de derecho, además del procedimiento especial para la concesión de la autorización al Ejecutivo para celebrar tratados ${ }^{23}$. Respecto a la recepción de la norma internacional, se identifican principalmente dos sistemas de recepción: la automática, que responde a la regla anglosajona: International is a part of the law of the land, y la especial, que requiere de un mecanismo de conversión de la norma internacional en norma interna ${ }^{24}$. Integrada la norma internacional al derecho interno, se plantea la cuestión de la determinación de los vínculos entre ambos ordenamientos, a partir de dónde se ubica la norma internacional en el sistema de fuentes del derecho interno ${ }^{25}$.

Esta visión desde adentro, en nuestro ordenamiento jurídico interno, se concreta en una recepción automática que se expresa en el artículo 55 de la Constitución Política y que dispone que los tratados celebrados en vigor formen parte del derecho nacional, otorgándoseles rango de ley en el artículo 200.4 de la Carta Magna. En principio, los tratados son la única fuente del derecho internacional que regula el ordenamiento jurídico peruano, ignorándose a las otras fuentes de aquel ordenamiento jurídico, como la costumbre internacional ${ }^{26}$.

Otra de las fuentes del derecho internacional, que ha sido regulada en el ordenamiento jurídico peruano a través del Código Procesal Constitucional, es la jurisprudencia internacional ${ }^{27}$. El TC ha recurrido a ella

23 Véase Constitución española de 1978 en http://www.congreso.es/consti/constitucion/indice/titulos/articulos.jsp?ini=93\&fin=96\&tipo=2

24 Véase Constitución española de 1978.

25 González, Sánchez \& Sáenz (1990, p. 221) plantean cuál es la posición de las normas internacionales en el sistema jurídico estatal.

26 De manera excepcional, en la Constitución Política del Estado podemos encontrar mención de algunas normas de derecho internacional consuetudinario, v.g., las referidas a las libertades de comunicación en el artículo 54.

27 Código Procesal Constitucional (Ley 28237, promulgada el 28 de mayo de 2004, publicada en el diario Oficial El Peruano el 31 de mayo de 2004, en vigencia de conformidad con la segunda disposición transitoria y derogatoria el 30 de noviembre de 2004). 
- principalmente a la de los tribunales internacionales de derechos humanos y, luego, a la de los tribunales penales internacionales- en la parte argumentativa de sus sentencias, como herramienta de interpretación de las normas constitucionales ${ }^{28}$.

Artículo V.- Interpretación de los derechos constitucionales: El contenido y alcances de los derechos constitucionales protegidos por los procesos regulados en el presente Código deben interpretarse de conformidad con la Declaración Universal de Derechos Humanos, los tratados sobre derechos humanos, así como de las decisiones adoptadas por los tribunales internacionales sobre derechos humanos constituidos según tratados de los que el Perú es parte.

El Tribunal Constitucional recurrió a esta fuente del derecho internacional en su jurisprudencia antes de la aprobación del Código Procesal Constitucional.

28 Tribunal Constitucional. Exp. 2798-2004-HC, sentencia aclaratoria de 11 de febrero de 2005. Caso Vera Navarrete, párr. 15. “Las normas señaladas en el punto anterior se aplican en tanto exista un conflicto armado interno entre fuerzas del Estado y grupos armados particulares. La jurisprudencia internacional ha indicado que las normas mínimas del Derecho Internacional Humanitario no solo se establecen con fines de mero reconocimiento, sino que su violación constituye una grave infracción humanitaria y, eventualmente, un crimen de guerra (Corte Internacional de Justicia, sentencia de fondo en el caso del estrecho de Corfú - 1949; de igual manera en la sentencia sobre actividades militares y paramilitares en y contra Nicaragua - 1986)" (énfasis agregado). Tribunal Constitucional. Exp. 0217- 2002-HC/TC, párr. 2: “De conformidad con la IV Disposición Final y Transitoria de la Constitución Política del Estado, los derechos y libertades reconocidos en la Constitución deben interpretarse de conformidad con los tratados internacionales en materia de derechos humanos suscritos por el Estado Peruano. Tal interpretación, conforme con los tratados sobre derechos humanos, contiene, implícitamente, una adhesión a la interpretación que, de los mismos, hayan realizado los órganos supranacionales de protección de los atributos inherentes al ser humano y, en particular, el realizado por la Corte Interamericana de Derechos Humanos, guardián último de los derechos en la Región" (énfasis agregado). Tribunal Constitucional. Exp. 218-02-HC/TC, párr. 2. Tribunal Constitucional. Exp. 12612002-HC/TC, párr. 2: “De conformidad con la Cuarta Disposición Final y Transitoria de la Constitución Política del Estado, los derechos y libertades reconocidos en la Constitución deben interpretarse, en materia de derechos humanos, con arreglo a los tratados internacionales suscritos por el Estado Peruano. Para casos similares al presente, la Corte Interamericana de Derechos Humanos ha señalado que "toda persona sujeta a un juicio de cualquier naturaleza ante un órgano del Estado, deberá contar con la garantía de que dicho órgano sea competente, independiente e imparcial" (Caso Tribunal Constitucional del Perú, en Sergio Garreta Ramírez, Jurisprudencia de la Corte Interamericana de Derechos Humanos-Universidad Autónoma de Méjico 2001, pág. 417, párrafo 77) [...]" (énfasis agregado). 
El TC, en su sentencia del Pleno jurisdiccional, recaída en el expediente $047-2004-\mathrm{AI} / \mathrm{TC}^{29}$, analiza el sistema de fuentes consagrado en la Constitución e identifica a las fuentes normativas con rango de ley, entre ellas al tratado, señalando sus diferencias con otras fuentes normativas en razón de que su modo de producción se rige por el derecho internacional público y en razón de su origen: el mandato constitucional.

En resumen, salvo los tratados y la jurisprudencia internacional, las otras fuentes del derecho internacional no han sido ni reguladas en nuestro ordenamiento jurídico nacional. Ello no ha sido óbice para que el TC haya recurrido a las normas del derecho internacional general o derecho internacional consuetudinario en la parte argumentativa de sus sentencias, como es el caso de las normas de ius cogens, fundándose en que esta categoría normativa se encuentra recogida en la Convención de Viena de 1969 sobre el Derecho de los Tratados, de la que es parte el Perú.

\section{Las normas de ius cogens ${ }^{30}$}

En sus orígenes, el concepto de ius cogens ha estado ligado particularmente al derecho de los tratados, siendo formulado en los artículos

29 Tribunal Constitucional. SENTENCIA DEL PLENO JURISDICCIONAL de 24 de abril de 2006. Expediente 047-2004-AI/TC. Demanda de inconstitucionalidad presentada por José Claver Nina-Quispe Hernández, en representación del Gobierno Regional de San Martín, de la Ley № 27971 por vulnerar el artículo $103^{\circ}$ de la Constitución Política del Estado. El demandante alega que la Ley 27971 vulnera el artículo $103^{\circ}$ de la Constitución Política del Estado, la autonomía de los gobiernos regionales contemplada en el artículo $191^{\circ}$ de la Constitución, transgrediéndose artículos de la Ley Orgánica de Gobiernos Regionales y de la Ley de Bases de Descentralización. El Tribunal al analizar el Sistema de Fuentes regulado por la Constitución en el derecho peruano, señala que esta consagra diversos tipos normativos tales como las fuentes normativas o formas normativas con rango de ley, fuentes normativas con rango distinto a la ley, jurisprudencia, costumbre, principios generales del derecho, contrato y la doctrina. Al referirse a las primeras, es decir a las normas o formas normativas con rango de ley, incluye a los tratados, que expresan un acuerdo de voluntades entre sujetos de derecho internacional, siendo su modo de producción regido por el derecho internacional público, y formando parte de nuestro sistema de fuentes de derecho porque la Constitución así lo determina, y no porque nace del derecho interno. Respecto a los tratados, el Tribunal Constitucional distingue entre tratados con habilitación legislativa, tratados ordinarios y convenios internacionales ejecutivos.

30 También denominadas normas imperativas o normas perentorias. 
$53^{31}$ y $64^{32}$ de la Convención de Viena de 1969 sobre el Derecho de los Tratados, sin perjuicio de que "[e]n su evolución y por su propia definición, el jus cogens no se ha limitado al derecho de los tratados. El dominio del jus cogens se ha ampliado, alcanzando también el derecho internacional general, y abarcando todos los actos jurídicos"33.

Como señala la Corte Interamericana de Derechos Humanos, el "ius cogens se ha manifestado [...] también en el derecho de la responsabilidad internacional de los Estados, y ha incidido, en última instancia, en los propios fundamentos del orden jurídico internacional"34, que en nuestro mundo contemporáneo atiende a "la necesidad de un mínimo de verticalización en el ordenamiento jurídico internacional, erigido sobre pilares en que se fusionan lo jurídico y lo ético", como señala Antonio Cançado Trindade ${ }^{35}$, quien además advierte de "la manifiesta incompatibilidad con el concepto de jus cogens de la concepción voluntarista del derecho internacional".

\subsection{Ius cogens como principio y norma}

Encontramos en la doctrina una doble significación del término ius cogens: como principio y como norma, pero en ambos casos su contenido conformará el orden público internacional ${ }^{36}$.

31 Convención de Viena de 1969 sobre el Derecho de los Tratados. Artículo 53. Tratados que están en oposición con una norma imperativa de derecho internacional general (jus cogens). "Es nulo todo tratado que, en el momento de su celebración, esté en oposición con una norma imperativa de derecho internacional general. Para los efectos de la presente Convención, una norma imperativa de derecho internacional general es una norma aceptada y reconocida por la comunidad internacional de Estados en su conjunto como norma que no admite acuerdo en contrario y que solo puede ser modificada por una norma ulterior de derecho internacional general que tenga el mismo carácter".

32 Convención de Viena de 1969 sobre el Derecho de los Tratados. Artículo 64. Aparición de una nueva norma imperativa de derecho internacional general (jus cogens). "Si surge una nueva norma imperativa de derecho internacional general, todo tratado existente que esté en oposición con esa norma se convertirá en nulo y terminará".

33 Corte IDH. Opinión Consultiva OC-18/03 de 17 de septiembre de 2003, solicitada por los Estados Unidos Mexicanos. Condición jurídica y derechos de los migrantes indocumentados, párrs. 98-99.

34 Ibídem, párr. 99.

35 Ibídem. Voto concurrente del juez Antonio Cançado Trindade, párr. 66.

36 Gómez Robledo (2003, p. 123). Acosta Estévez (1995, pp. 3-22) señala que, para algunos autores, las normas de ius cogens responden al mínimo jurídico esencial 
La naturaleza de norma del ius cogens la resalta el profesor Paul Guggenheim, quien refiere que este término aparece acuñado por los pandectistas a fines del siglo XVIII:

La expresión Ius cogens aparece por primera vez, a lo que creemos, en los pandectistas. Fue sobre todo Windscheid quien trató de definir el Ius cogens como el conjunto de reglas jurídicas que excluyen toda actitud arbitraria de las personas privadas; reglas que se aplican y se imponen aun en la hipótesis de que las partes quisieran excluirlas ${ }^{37}$ (enfasis agregado).

Para Eduardo Suárez, representante mexicano en la Conferencia de Viena de 1969 sobre el Derecho de los Tratados, los principios de ius cogens han existido siempre, considerando que

[...] la apariencia de un surgimiento reciente de esa noción se debe más bien a que los Estados han abusado de un poder antaño ilimitado que contradice el carácter necesariamente limitado de sus atribuciones, y a que no se había intentado codificar esos principios"38.

Suárez agrega que son

[...] aquellos principios que la conciencia jurídica de la humanidad, revelada por sus manifestaciones objetivas, considera como absolutamente indispensable para la coexistencia y la solidaridad de la comunidad internacional en un momento determinado de su desarrollo orgánico ${ }^{39}$ (énfasis agregado).

Por su parte, la Corte Interamericana de Derechos Humanos, en su Opinión consultiva sobre condición jurídica y derechos de los migrantes indocumentados, señala que el principio de igualdad ante la ley y no discriminación pertenece al ius cogens, "puesto que sobre él descansa todo el andamiaje jurídico del orden público nacional e internacional y es un principio fundamental que permea todo ordenamiento jurídico" 40 .

\footnotetext{
del "orden público internacional" y cita a Schwarzenberger G: Internacional ius cogens, en Texas Law Review, 1965, vol. 43, p. 456; y De Visscher, Ch.: Positivismo et ius cogens, en RGDIP, 1971, pp. 8, 9 .

37 Citado por Maureira Santis (s. f., p. 3).

38 Citado por Vallarta Marrón (2010).

39 Intervención del representante mexicano en la Conferencia de Viena (1969), Eduardo Suárez. En: ONU. Documento ONU A/CONF.39/11, sesión 52, párrs. 7 y 8.

40 Corte IDH. Opinión Consultiva OC-18/03 de 17 de septiembre de 2003, solicitada por los Estados Unidos Mexicanos. Condición jurídica y derechos de los migrantes indocumentados, párr. 101.
} 


\subsection{La naturaleza consuetudinaria de las normas de ius cogens}

Como sostiene Rafael Nieto Navia:

La noción de jus cogens no es tan nueva [...]. En realidad, el derecho de gentes reconocía ya en la antigüedad la existencia de ciertas normas superiores que tan solo desaparecieron con el positivismo del siglo XIX para reaparecer en el siglo XX, aunque sobre bases totalmente distintas, menos litigiosas ${ }^{41}$.

El origen consuetudinario de la norma de ius cogens se respalda en el derecho interno. Así, Rienstel Stetan - citado por el profesor Antonio Gómez Robledo - refiere la sentencia de la Corte Suprema Constitucional de la República Federal Alemana, de 7 de abril de $1965^{42}$, la que expresa:

El Derecho Internacional de los tratados tiene por lo general prioridad sobre el derecho consuetudinario, ya que se trata de un derecho posterior y más especial. Únicamente un pequeño número de normas jurídicas elementales puede considerarse como normas de derecho internacional consuetudinario que no pueden derogarse por tratado. Este carácter lo tienen solamente aquellas normas perentorias que están firmemente arraigadas en la convicción jurídica de la comunidad de naciones y que son indispensables a la existencia del derecho de las naciones como un orden jurídico internacional, cuya observancia puede exigirse por todos los miembros de la comunidad internacional [énfasis agregado] (Gómez, 2003, p. 108).

41 Conferencia de las Naciones Unidas sobre el Derecho de los Tratados. Primer Periodo de Sesiones (1968), doc. A/Conf.39/11, 334 (“Conf. Viena 1968”). Ver, en general, Nieto Navia (junio de 1977, pp. 259 ss.). Véase, también, Maureira Santis (s. f., p. 3). “La recepción de las Normas de Ius Cogens en la Convención de Viena sobre el derecho de los tratados, significó una profunda innovación, por cuanto se tradujo en la plena incorporación al derecho internacional positivo de una institución que hasta entonces solo era considerada por la doctrina y la jurisprudencia internacional. La institución es tan antigua como el derecho internacional, aun cuando solo se haya acuñado el término a finales del Siglo XVIII". Citando al profesor Paul Guggenheim, añade que dicho término fue acuñado por los pandectistas a finales del siglo XVIII, y se definía como el conjunto de "reglas jurídicas que excluyen toda actitud arbitraria de las personas privadas; reglas que se aplican y se imponen aún en la hipótesis de que las partes quisieran excluirlas".

42 En un caso entre Alemania y la Confederación Helvética. 


\subsection{Objeto de las normas de ius cogens}

La Comisión de Derecho Internacional ha señalado que "no es la forma de una norma general de derecho internacional la que le da el carácter de Ius Cogens, sino la especial naturaleza de su objeto" (Gómez, 2003, p. 125), por lo que exige que "sean el fiel reflejo de los intereses mayoritarios de la comunidad internacional, intereses que, por lo demás, son concebidos en todo su dinamismo" (Gómez, 2003, p. 108). Agrega que, en ese propósito, la comunidad internacional reconoce ciertos principios que salvaguardan valores de importancia vital para la humanidad y que traduce normativamente, de modo que "Estas reglas interesan a todos los Estados y protegen intereses que no se limitan a un Estado o a un grupo de Estados, sino que afectan a la comunidad internacional" (Gómez, 2003, p. 123).

\subsection{Características de las normas de ius cogens}

\subsubsection{De la inderogabilidad de la norma de ius cogens}

Sin perjuicio de la naturaleza consuetudinaria de la norma de ius cogens y del respaldo de su existencia en la jurisprudencia internacional, la Convención de Viena de 1969 sobre el Derecho de los Tratados ${ }^{43}$, en sus artículos 53 y 64, al tratar sobre la nulidad y la terminación de tratados, respectivamente, define la norma de ius cogens como:

[...] una norma de naturaleza consuetudinaria aceptada y reconocida por la comunidad internacional de Estados en su conjunto como norma que no admite acuerdo en contrario y que solo puede ser modificada por una norma ulterior de derecho internacional general que tenga el mismo carácter.

En ese sentido, es nula la norma de un tratado que se oponga a una norma de ius cogens, o esta termina si se opone a "una nueva norma imperativa de derecho internacional general".

43 En el marco del procedimiento interno de perfeccionamiento, mediante D.S. 029-2000-RE, de 14 de setiembre de 2000, se ratificó la Convención de Viena de 1969 sobre el Derecho de los Tratados. En el marco del procedimiento internacional, el instrumento de ratificación se depositó el 14 de setiembre de 2000, entrando en vigencia para el Perú el 14 de octubre de 2000. 


\subsubsection{De la no admisión de acuerdo en contrario}

De acuerdo con José Acosta Estévez, las normas imperativas o de ius cogens no admiten acuerdo en contrario, "ya que protegen los intereses fundamentales o esenciales que la comunidad internacional precisa para su supervivencia y, en consecuencia, imposibilitan a los sujetos el sustraerse de las mismas" (1995, pp. 3-22), por lo que no existen para "satisfacer las necesidades de los Estados en particular, sino de los más altos intereses de la comunidad internacional en su conjunto" (Verdross, 1978). En ese sentido, Acosta Estévez agrega que "las normas de ius cogens están por encima de las voluntades estatales" y que su existencia está avalada en la jurisprudencia internacional ${ }^{44}$. De este modo, la norma internacional que no admite pacto en contrario introduce una jerarquía normativa, impensable en el derecho internacional clásico, pero que caracteriza al derecho internacional contemporáneo, que

[...] no se reduce solamente a ser un producto resultante de la voluntad de los Estados, sobre la base del principio de la soberanía estatal, sino que la autonomía de la voluntad de los Estados es limitada, pues los conceptos abstractos de libertad y de soberanía absoluta de los Estados son incompatibles con la existencia misma de una sociedad internacional (Acosta, 1995).

\subsubsection{De los efectos erga omnes de las normas de ius cogens}

Como afirma el profesor Roberto Ago, "las normas imperativas podrían provenir tanto del derecho consuetudinario como del convencional, y que al adquirir tal carácter obligarían erga omnes y no solo a las partes del tratado internacional" (Vallarta, 2010, p. 16). En la misma línea, Vallarta expresa que "Por definición, todas las normas del ius cogens

44 Acosta Estévez afirma que a esa fecha la jurisprudencia internacional se había referido tanto de forma directa como indirecta a la noción de norma imperativa, tanto por la Corte Permanente de Justicia como por la Corte Internacional de Justicia, citando el asunto Oscar Chinn (CPJI. Serie A/B, núm. 63, pp. 149 y 150), asunto sobre las reservas a la Convención para la prevención y sanción del crimen de genocidio (CIJ, Recueil, 1951, p. 23), el caso del Derecho de Paso (CIJ, Recueil, 1960, p. 34), en el asunto del Sudoeste africano segunda fase (CIJ, Recueil, 1966, pp. 258 y ss.) y en los asuntos relativos a la Plataforma Continental del Mar del Norte (CIJ, Recueil, 1969, pp. 24-46). Posteriormente, ha continuado su desarrollo jurisprudencial incluyendo la jurisprudencia de los tribunales de derechos humanos como la Corte Interamericana de Derechos Humanos. 
generan necesariamente obligaciones erga omnes" 46 . Añade que, sin perjuicio de que no todas las obligaciones erga omnes se refieren necesariamente a normas del ius cogens, dichas obligaciones

[...] están dotadas de un carácter necesariamente objetivo, comprometiendo a todos los destinatarios de la normativa internacional de protección (omnes), los agentes del poder público así como los que actúan a título personal o los que operan en el anonimato y la clandestinidad. De ahí la importancia del deber general de los Estados de respetar, y asegurar el respeto, de los derechos protegidos, en todas las circunstancias (2010, p. 16).

$\mathrm{Al}$ determinar la naturaleza de ius cogens del principio de igualdad y no discriminación, la Corte Interamericana se refirió de modo implícito a los efectos erga omnes de esta calificación:

[...] puede considerarse efectivamente como imperativo del derecho internacional general, en cuanto es aplicable a todo Estado, independientemente de que sea parte o no en determinado tratado internacional, y genera efectos con respecto a terceros, inclusive a particulares ${ }^{47}$.

\subsubsection{Indeterminación de las normas de ius cogens}

Si bien las normas de ius cogens interesan a todos los Estados y protegen intereses que no se limitan a un Estado o grupo de Estados, sino que afectan a la comunidad internacional (Gómez, 2003, p. 123), no hay un texto en donde se enumeren. Algunos autores, como Julio González Campos, señalan la existencia de "textos internacionales donde indudablemente se recogen normas de ius cogens, tales como la Resolución 2625 (XXV), de 24 de octubre de 1970, del Proyecto de artículos sobre responsabilidad internacional de los Estados" (González, Sánchez \& Sáenz, 1990, pp. 50-51). Para Carrillo Salcedo, en el derecho internacional contemporáneo, son normas de ius cogens las relativas a algunos de los

45 Vallarta Marrón (2010, p. 16): “Mientras el Ius Cogens es un concepto de derecho material, las obligaciones erga omnes se refieren a la estructura de su desempeño por parte de todas las entidades y todos los individuos obligados".

46 Corte IDH. Opinión Consultiva OC-18/03 de 17 de septiembre de 2003, solicitada por los Estados Unidos Mexicanos. Condición jurídica y derechos de los migrantes indocumentados, párr. 100. 
derechos fundamentales de la persona humana, que todo Estado tiene el deber de respetar y proteger, así como las relativas a la existencia misma de los Estados, como la prohibición del recurso al uso de la fuerza o la amenaza de fuerza en las relaciones internacionales, la obligación de arreglo pacífico de las controversias internacionales, la igualdad de estatus jurídico de los Estados, y el principio de no intervención en asuntos que sean de la jurisdicción interna de los Estados ${ }^{48}$. En la práctica, las normas de ius cogens vienen siendo identificadas por la jurisprudencia internacional. Así, para la Corte Interamericana de Derechos Humanos, en la actual etapa de la evolución del derecho internacional, el principio fundamental de igualdad y no discriminación ha ingresado en el dominio del ius cogens ${ }^{49}$.

Dadas las características de las normas de ius cogens -inderogabilidad, salvo por otra norma del mismo carácter; no admisión de acuerdo en contrario, e incorporación de jerarquía normativa en el derecho internacional; y efectos erga omnes -, estas conformarían un orden público internacional, cuyos sujetos - v.g.: los Estados, las organizaciones internacionales, la persona humana, los movimientos de liberación nacional; y los sujetos clásicos: Iglesia Católica, Orden Soberana de Malta, beligerantes, Comité Internacional de la Cruz Roja -, y todos aquellos otros que sean reconocidos en el futuro, deben observarlas (Alfaro, 1989, p. 107).

\section{La jurisprudencia del Tribunal Constitucional y las normas de ius cogens}

La existencia de los tribunales constitucionales responde al fenómeno del constitucionalismo ${ }^{50}$, que representa el complemento del Estado de Derecho y que importa la sujeción de todos los poderes a la ley ordina-

47 Carrillo Salcedo (1976, p. 284), citado por Acosta Estévez (1995, pp. 3-22).

48 Corte IDH. Opinión Consultiva OC-18/03 de 17 de septiembre de 2003, solicitada por los Estados Unidos Mexicanos. Condición jurídica y derechos de los migrantes indocumentados, párr. 101.

49 Ferrajoli (julio-diciembre de 2006, pp. 114-115). Ferrajoli define el constitucionalismo como un "sistema de vínculos sustanciales, o sea de prohibiciones y de obligaciones impuestas por las cartas constitucionales, y precisamente por los principios y derechos fundamentales en ellas establecidos, a todos los poderes públicos, incluso al legislativo" (p. 114), y lo considera "el legado más importante de siglo XX [...] y [...] sobre todo, un programa normativo para el futuro" (p. 115). 
ria y/o constitucional ${ }^{50}$, cuyo contenido no es otro que los principios y derechos fundamentales que, al ser "establecidos en las constituciones estatales y por las cartas internacionales, deben ser garantizados y concretamente satisfechos", lo cual exige "la implementación de técnicas de garantías idóneas para asegurar el máximo grado de efectividad a los derechos constitucionalmente reconocidos" (Ferrajoli, julio-diciembre de 2006, pp. 114). De este modo, el Tribunal Constitucional, máximo intérprete de la Constitución, vela por que no se vulnere la Carta Magna, y le "corresponde [...] reafirmar su compromiso con la tutela de los derechos fundamentales y el respeto al principio jurídico de supremacía constitucional" 51 .

En nuestro estudio hemos encontrado sentencias en donde una de las partes invoca la naturaleza de ius cogens de algunas normas y el TC no se pronuncia respecto a ellas, en el sentido de definirlas o establecer su naturaleza o sus efectos; en otras sentencias, esas normas han sido tratadas en votos razonados y, en otras, el TC sí las ha valorado. En este trabajo mencionaremos algunas sentencias para ejemplificar la primera y la tercera situaciones ${ }^{52}$.

4.1 Primer caso. Sentencias en las que las normas de ius cogens son invocadas por una de las partes y no son analizadas por el TC

4.1.1 Sentencia del Pleno Jurisdiccional del Tribunal Constitucional en el caso de Juan Carlos Díaz Montes y 8971 ciudadanos (demandante) c. Congreso de la República (demandado), resolución del 13 de febrero de 2009.

El proceso de inconstitucionalidad se dirige contra el artículo 7 de la Ley 27765 - "Ley Penal contra el Lavado de Activos", que prohíbe los beneficios penitenciarios de redención de la pena por el trabajo y la educación, semilibertad y liberación condicional para los sentenciados por el delito previsto en el último párrafo del

50 En ese sentido, la Constitución no es simplemente producto del legislador, sino también proyección jurídica de la legislación misma, que limita y vincula al legislador. Ferrajoli (julio-diciembre de 2006, pp. 114).

51 Tribunal Constitucional. Sentencia de 11 de diciembre de 2008. Expediente 03173-2008-PHC/TC LIMA, TEODORICO BERNABÉ MONTOYA, voto singular del magistrado Landa Arroyo, palabras iniciales.

52 En un próximo desarrollo del tema que es objeto del presente trabajo, nos ocuparemos de la segunda situación, es decir, los votos razonados en los que se analiza el concepto de ius cogens y sus implicancias en el derecho peruano. 
artículo 3 de la mencionada Ley ${ }^{53}$, y - por conexidad - contra el primer y el tercer párrafo del artículo 4 de la Ley $26320^{54}$. La demanda de inconstitucionalidad solicita que se declare la inconstitucionalidad de las disposiciones impugnadas que prohíben el acceso a los beneficios penitenciarios para un grupo de la población carcelaria de condenados por delitos agravados de Tráfico Ilícito de Drogas porque considera que son contrarias a los "fines de las penas" (artículo 139, inciso 22, de la Constitución), y que se vulnera el principio de "igualdad jurídica" ante la ley y el principio de no discriminación, al que se califica de "jus cogens" por haberlo así determinado la Corte Interamericana de Derechos Humanos en su Opinión Consultiva 18, del 17 de setiembre de $2003^{55}$, lo que obligaría al Estado a eliminar las regulaciones de carácter discriminatorio de su ordenamiento jurídico.

Para el demandante, "la variación o la aparición de nuevas doctrinas como la incorporación de un derecho fundamental a la categoría de Normas Imperativas de Derecho Internacional General (jus cogens) harían variar sustancialmente el contenido de las leyes internas". Señala además que dichas normas están "fuera del límite temporal", por lo que dejar de pronunciarse respecto a ellas "significaría violar el derecho al debido proceso y el principio de no dejar de administrar justicia por vacío o deficiencia de la ley, reconocido en el artículo 139, inciso 8), de la Constitución".

El demandante enfatiza sobre la naturaleza imperativa de derecho internacional general del principio de igualdad y no discriminación desde el año $2003^{56}$, aunque sustenta la fuerza vinculante para el Perú en su calidad de Estado "parte" de la Convención Americana de Derechos Humanos, lo que contradice su naturaleza consuetudinaria, resaltando su imposibilidad de aplicar al caso concreto cualquier norma de derecho interno que pueda restringir por razones temporales o de otra naturaleza el acceso a la tutela judicial efectiva.

53 Publicada el 27 de junio de 2002 en el diario oficial El Peruano.

54 Publicada el 2 de junio de 1994 en el diario oficial El Peruano.

55 Corte Interamericana de Derechos Humanos. Opinión Consultiva OC-18/03, de 17 de septiembre de 2003, Condición jurídica y derechos de los migrantes indocumentados, solicitada por los Estados Unidos Mexicanos.

56 En relación con la fecha de la Opinión Consultiva OC-18 de la Corte Interamericana de Derechos Humanos. 
El TC, en el párrafo 84 de su sentencia, sin pronunciarse sobre la naturaleza de ius cogens del principio de igualdad, precisa que es una norma-principio cuyos efectos se van a desplegar en todo el ordenamiento jurídico peruano.

\subsection{Segundo caso. Sentencias en las que el TC invoca las normas de ius cogens en la parte considerativa}

4.2.1 Sentencia de 23 de marzo de 2010, recaída en el expediente 00018-2009PI/TC. LIMA, interpuesta por el Colegio de Abogados del Callao

Jorge Antonio Guizado Salcedo, decano del Colegio de Abogados del Callao, presenta una demanda de inconstitucionalidad contra la Resolución Legislativa 2799857, que aprueba la adhesión del Perú a la Convención sobre la imprescriptibilidad de los crímenes de guerra y de los crímenes de lesa humanidad. El demandante afirma que dicha resolución "ha sido aprobada contraviniendo el *segundo párrafo* del artículo 57ํy y el artículo 206º de la Constitución, que establecen que si un tratado afecta disposiciones constitucionales, debe ser aprobado por el mismo procedimiento que rige para la reforma de la Constitución antes de ser ratificado por el Presidente de la República". Agrega que "el referido instrumento internacional afecta el artículo 139, inciso 13, de la Constitución $-{ }^{*}$ que recoge la institución de la prescripción para toda clase de delitos ${ }^{*}-$, toda vez que excluye el derecho a gozar de la prescripción de la acción penal para aquellos delitos considerados como crímenes de guerra y crímenes de lesa humanidad...".

El TC, en su fundamento jurídico 4, señala que el objeto de la convención referida "es dotar a los Estados de mecanismos que permitan investigar y sancionar a los presuntos responsables de las graves violaciones a los Derechos Humanos y al Derecho Internacional Humanitario que se constituyen como crímenes de derecho internacional, en el que la obligación de prevención y sanción es una norma de Ius Cogens".

En esta sentencia, el TC, al determinar los alcances de dicha convención, determina asimismo que las obligaciones de prevención y sanción de dichos crímenes internacionales que se derivan de este tratado son normas de ius cogens. No define la norma de ius cogens:

57 Publicada el 12 de junio de 2003 en el diario oficial El Peruano. 
solo declara que las graves violaciones a los derechos humanos y al derecho internacional humanitario son crímenes de derecho internacional - es decir, aquellas cometidas tanto en tiempo de paz como de conflicto armado-, y respecto a ellas existe la obligación de su prevención y sanción. En ese sentido, el TC se refiere de modo implícito a la naturaleza consuetudinaria e imperativa de dicha obligación y a los efectos erga omnes que de ella se derivan; así como a su plena eficacia jurídica en el ordenamiento jurídico peruano.

4.2.2 Sentencia del Pleno Jurisdiccional de 21 de marzo de 2011, recaída en el expediente 0024-2010-PI/TC. LIMA

Con fecha 9 de setiembre de 2010, un $25 \%$ del número legal de congresistas presenta una demanda de inconstitucionalidad contra los artículos 1 y 2 del Decreto Legislativo 1097, que tienen el siguiente texto:

Artículo 1. Objeto: El presente Decreto Legislativo tiene por objeto adelantar la vigencia de algunos artículos del Nuevo Código Procesal Penal, aprobado por Decreto Legislativo № 957, a todos los Distritos Judiciales del país, con la finalidad de establecer un marco regulatorio uniforme respecto de los delitos que implican violación de derechos humanos.

Artículo 2.- Alcance: El presente Decreto Legislativo es de aplicación a los procesos por los delitos contra la Vida, el Cuerpo y la Salud previstos en el Código Penal de 1924 y el Código Penal de 1991, considerados como violaciones a los derechos humanos, así como por los delitos contra la Humanidad previstos en el Código Penal de 1991.

Los congresistas demandantes consideran que el Decreto Legislativo 1097 es violatorio del principio-derecho a la igualdad, reconocido en el artículo 2, inciso 2, y en el primer párrafo del artículo 103 de la Constitución; y del mandato contenido en el artículo 2 de la Convención Americana sobre Derechos Humanos ${ }^{58}$, sobre el deber del Estado peruano de adoptar medidas de derecho interno.

58 Convención Americana sobre Derechos Humanos. Artículo 2. Deber de adoptar disposiciones de derecho interno. Si el ejercicio de los derechos y libertades mencionados en el artículo 1 no estuviere ya garantizado por disposiciones legislativas o de otro carácter, los Estados partes se comprometen a adoptar, con arreglo a sus procedimientos constitucionales y a las disposiciones de esta Con- 
Refieren que el decreto legislativo impugnado establece "un trato diferenciado en relación con la aplicación de la legislación procesal penal, en razón de las diferencias de las personas". Sostienen que, respecto a dichas medidas, solo son beneficiarios los policías y los militares acusados de la violación de derechos humanos, lo que introduce un trato discriminatorio bajo el criterio de la profesión $\mathrm{u}$ oficio, el tipo de delito por el que se es procesado y la condición económica del imputado, lo cual a su vez viola el artículo 2 de la Convención Americana. Afirman que el decreto legislativo incoado adopta medidas que colocan en una situación de indefensión a las víctimas de violaciones de los derechos humanos y otorgan impunidad y beneficios a los violadores de esos derechos.

El TC, en el fundamento jurídico 7.3 ("Las normas de ius cogens"), numeral 53 de la sentencia, señala que el derecho a la verdad, así como la obligación de procesar y sancionar a los responsables de crímenes de lesa humanidad, constituye una norma de ius cogens:

53. La esencial ontología de los derechos humanos afectados por los crímenes de lesa humanidad, y las graves condiciones y circunstancias que caracterizan la realización de estos, lleva a considerar que, en estos casos, la necesidad de la averiguación de la verdad, así como el procesamiento y posterior sanción de los responsables, constituye una norma de ius cogens, es decir, una norma imperativa de Derecho Internacional susceptible de aplicarse erga omnes y que no admite pacto en contrario.

El TC precisa que todo pacto en contrario a las normas de ius cogens es nulo:

53. $[\ldots]$

En relación con la normas de ius cogens, el artículo $53^{\circ}$ de la Convención de Viena sobre el Derecho de los Tratados establece lo siguiente: "Es nulo todo tratado que en el momento de su celebración esté en oposición con una norma imperativa de derecho internacional general. Para los efectos de la presente Convención, una norma imperativa de derecho internacional general es una norma aceptada y reconocida por la comunidad internacional de Estados en su conjunto como norma que no admite acuerdo en contrario y que solo puede ser

vención, las medidas legislativas o de otro carácter que fueren necesarias para hacer efectivos tales derechos y libertades. 
modificada por una norma ulterior de derecho internacional general que tenga el mismo carácter".

Enfatiza su naturaleza consuetudinaria e inderogable:

53. $[\ldots]$

Las normas de ius cogens parecen pues encontrarse referidas a normas internacionales consuetudinarias que bajo el auspicio de una opinio iuris sive necessitatis - esto es, el factor espiritual o psicológico que liga con un comportamiento que se asume debido $\mathrm{u}$ obligatorio internacionalmente - y de la extraordinaria importancia de los valores que subyacen a tal obligación, son oponibles más allá de las voluntades expresas y solo son derogables por normas futuras de la misma categoría.

En el numeral 62 de la sentencia, el TC concluye que la regla de la imprescriptibilidad de los delitos de lesa humanidad y del mandato de su persecución con prescindencia de la fecha en que se cometieron no tiene vigencia en el ordenamiento jurídico peruano, pero no

62. [...] como consecuencia de la entrada en vigor de la Convención sobre la Imprescriptibilidad de los Crímenes de Guerra y de los Crímenes de Lesa Humanidad (9 de noviembre de 2003), sino que surge en virtud de una norma imperativa de derecho internacional general que, como ha sostenido la Corte Interamericana, no nace de la referida Convención, sino que está reconocida en ella (Cfr. Caso La Cantuta vs. Perú, Sentencia del 29 de noviembre de 2006, párrafo 225).

El TC remarca la naturaleza consuetudinaria de la norma de ius cogens y de su proceso de formación mediante el elemento material - práctica estatal - y el elemento espiritual - psicológico $\mathrm{u}$ opinio iuris sive necessitatis - ; este último importa la convicción de estar actuando conforme al derecho internacional, así como la conciencia de poder incurrir en responsabilidad internacional por su incumplimiento, además de referirse a la naturaleza, efectos y características de la norma de ius cogens.

En esta sentencia, el TC identifica como norma de ius cogens a la obligación de perseguir, más allá de todo plazo, a los delitos de lesa humanidad, y considera que "la necesidad de la averiguación de la verdad, así como el procesamiento y posterior sanción de los 
responsables, constituye una norma de ius cogens" que obliga a todos, v.g., al Estado, a sus órganos y a los individuos.

Asimismo, resalta la relación que existe entre tratados y normas consuetudinarias al señalar que la Convención sobre imprescriptibilidad de los crímenes de guerra y de los crímenes de lesa humanidad sólo declara o reconoce dicha obligación pero no la constituye, porque esta es de naturaleza consuetudinaria.

Para el TC, obviar la obligación de perseguir los delitos de lesa humanidad también supondría desconocer las normas constitucionales:

Obviar esta obligación dimanante de la práctica internacional supone desconocer el contenido constitucional exigible del derecho fundamental a la verdad como manifestación implícita del principio-derecho a la dignidad humana (artículo 1 de la Constitución), del derecho fundamental a la tutela jurisdiccional efectiva (artículo 139, inciso 3, de la Constitución) y del deber del Estado de garantizar la plena vigencia de los derechos humanos (artículo 44 de la Constitución), siendo además un valor encaminado a la garantía plena de los derechos fundamentales a la vida (artículo 2, inciso 1, de la Constitución), a la integridad personal (artículo 2, inciso 1, de la Constitución), a la libertad personal (artículo 2, inciso 24, de la Constitución) y a la igualdad (artículo 2, inciso 2, de la Constitución), frente a sus muy graves violaciones.

El TC determina las implicancias para nuestro país en cuanto a la obligación de persecución en los casos de crímenes de lesa humanidad, los que no prescriben no como mandato de una norma convencional - la Convención sobre la imprescriptibilidad de los crímenes de guerra y de los crímenes de lesa humanidad, adoptada el 9 de noviembre de 2003- que solo lo reconoce así, sino como mandato de una norma imperativa de derecho internacional que así lo prescribe y cuya violación supondría también desconocer la norma constitucional peruana (v.g.: los artículos 1; 139, inciso 3; 44; 2, incisos 1, 24 y 2; de la Constitución Política del Perú).

De esta manera, estaríamos frente a una obligación internacional consuetudinaria reforzada por el derecho estatal peruano; es decir, la fuerza vinculante de las normas internacionales consuetudinarias imperativas - ius cogens -, en el ordenamiento jurídico peruano, se vería reforzada por nuestra propia Constitución. 
El TC concluye:

En virtud de dicho reconocimiento constitucional, y en atención a lo previsto por el artículo 55ํㅡ y la Cuarta Disposición Final y Transitoria de la Constitución, debe precisarse que la aludida regla de imprescriptibilidad constituye una norma de ius cogens derivada del Derecho Internacional de los Derechos Humanos, aplicable en todo tiempo, contra la que no cabe pacto en contrario, con fuerza erga omnes, y con plena eficacia en el ordenamiento jurídico peruano.

En consecuencia, la regla de la imprescriptibilidad por crímenes de lesa humanidad o de guerra, y la obligación de su persecución, forma parte del derecho nacional debido a la ratificación por nuestro país de la Convención sobre imprescriptibilidad de los crímenes de guerra y de los crímenes de lesa humanidad, y a la interpretación de la Declaración Universal de los Derechos Humanos y de otros tratados de derechos humanos de los que nuestro país es parte, pero también porque se trata de una norma de ius cogens con efectos erga omnes, y, en este caso, la obligación debe ser observada más allá de todo plazo, por todos los órganos estatales - incluyendo el Legislativo - y funcionarios del Estado. Su incumplimiento puede generar no solo efectos en el plano internacional - a través de la responsabilidad internacional-, sino también en el nacional, pues significaría desconocer el contenido constitucional, lo que evidencia las relaciones de coordinación y complementación entre el derecho internacional y el derecho estatal peruano, entre la norma internacional perentoria y la norma constitucional.

Como ha señalado el TC respecto a sus sentencias: "en los procesos de inconstitucionalidad [...] que queden firmes tienen autoridad de cosa juzgada, por lo que vinculan a todos los poderes públicos y producen efectos generales desde el día siguiente a la fecha de su publicación" 59 .

59 Sentencia del Pleno Jurisdiccional del Tribunal Constitucional del Perú del 3 de junio de 2005. Proceso de Inconstitucionalidad. Colegios de Abogados del Cusco y del Callao y más de cinco mil ciudadanos c/. Congreso de la República. Síntesis: Proceso de inconstitucionalidad contra la Ley $N^{\circ} 28389$, de reforma constitucional de régimen pensionario, y contra la Ley $N^{\circ} 28449$, de aplicación de nuevas reglas pensionarias previstas en el Decreto Ley $N^{\circ} 20530$, párr. 157. 
Así pues, las normas de ius cogens identificadas por el TC son vinculantes y obligatorias para todos los órganos del Estado, sus funcionarios y sus agentes, así como para toda persona que se encuentre bajo su jurisdicción.

\section{Conclusiones}

1. El desarrollo del derecho internacional en el siglo XX nos ha permitido visualizar que este ordenamiento jurídico está integrado por diversos tipos de normas. A la tradicional clasificación de normas escritas - convencionales - y normas no escritas - consuetudinarias-, locales, regionales y con vocación universal, en función de su ámbito espacial de aplicación, se pueden identificar normas que responden a las nuevas características del derecho internacional, así como a su relación con el derecho interno de los Estados a efectos de su eficacia: normas operativas - caracterizadas por su aplicación directa por sus destinatarios - y programáticas - requieren un desarrollo legislativo para su aplicación-; normas de hard law y de soft law; normas dispositivas - respecto de las cuales los Estados pueden pactar libremente- e imperativas o ius cogens - respecto de las cuales los Estados no pueden pactar.

2. El ius cogens es una categoría normativa abierta que se expande en la medida en que se despierta la conciencia jurídica universal, y responde a la necesidad de proteger los derechos y libertades fundamentales. Dicha expansión comprende a los ordenamientos internos de los Estados, como es el caso del derecho peruano, y su presencia e influencia se verifica a través de las decisiones del TC.

3. La tendencia del TC, de incorporar en la fundamentación de sus sentencias el ius cogens, va de acuerdo con la tendencia de limitación del voluntarismo estatal en el derecho internacional.

4. El recurso a normas e instituciones del derecho internacional público, por parte del TC, se lleva a cabo como una herramienta de interpretación para determinar los alcances de las obligaciones del Estado, estableciendo parámetros y límites al poder estatal en cuanto a las materias que califica como ius cogens $\mathrm{u}$ obligaciones con efectos erga omnes. Sin embargo, no podemos dejar de señalar que al referirse al contenido y alcances de la norma de ius cogens, el TC se remite a la Convención de Viena de 1969 sobre el Derecho de los Tratados -de la que es parte nuestro país por haberla ratificado el 14 se sep- 
tiembre de 2000, entrando en vigencia el 14 de octubre del mismo año-, evidenciando la interacción de ambas ramas del derecho en su afán de una mejor protección de los derechos y libertades fundamentales consagrados en nuestra Carta Magna.

\section{Referencias}

Acosta Estévez, J. B. (1995). Normas de ius cogens, efecto erga omnes, crimen internacional y la teoría de los círculos concéntricos. Anuario de Derecho Internacional. Navarra: Universidad de Navarra.

Alarcón García, G. (2010). El soft law y nuestro sistema de fuentes. Contribución al Libro-Homenaje del profesor Álvaro Rodríguez Bereijo. Murcia: Universidad de Murcia.

Alfaro Lanchipa, R. (1989). Los efectos de la norma de ius cogens en el derecho internacional público. (Tesis para optar el título de abogado). Universidad de Lima. Lima, Perú.

Barberis, J. (1973). Fuentes del derecho internacional. La Plata: Editora Platense.

Becerra Ramírez, M. (2005). Las nuevas fuentes del derecho internacional y su aplicación en el derecho interno. Recuperado de http:// biblio.juridicas.unam.mx/libros/4/1643/26.pdf

Camargo, P. P. (1983). Tratado de derecho internacional. Tomo I. Bogotá: Temis. Cançado Trindade, A. (2001). La interacción entre el derecho internacional y el derecho interno en la protección de los derechos humanos. En El derecho internacional de los derechos humanos en el siglo XXI. Santiago: Jurídica de Chile.

Carrillo Salcedo, J. (1976). Soberanía del Estado y derecho internacional. Madrid.

Corte IDH. (17 de setiembre de 2003). Opinión Consultiva OC-18/03 de 17 de septiembre de 2003, solicitada por los Estados Unidos Mexicanos. Condición jurídica y derechos de los migrantes indocumentados.

De la Guardia, E., \& Delpech M. (1970). El derecho de los tratados y la Convención de Viena de 1969. Buenos Aires: La Ley.

Diez de Velasco, M. (1976). Instituciones de derecho internacional público. Tomo I. Madrid: Tecnos.

Diez de Velasco, M. (1996). Instituciones de derecho internacional público. Tomo I. Madrid: Tecnos.

Ferrajoli, L. (julio-diciembre de 2006). Sobre los derechos fundamentales. Cuestiones Constitucionales, 15. México. UNAM. 
García San José, D. (2008). La elaboración de derecho internacional más allá del consentimiento estatal. La emergente legalidad internacional de base consensual. Anuario Español de Derecho Internacional, vol. XXIV. Recuperado de http://dspace.unav.es/dspace/bitstream/10171/21276/1/ADI_XXIV_2008_04.pdf

Gómez Robledo, A. (2003). El ius cogens internacional. Estudio histórico-crítico. México D. F.: UNAM, Instituto de Investigaciones Jurídicas.

González Campos, J. (1983). Curso de derecho internacional público. Vol. I. Universidad de Oviedo.

González Campos, J., Sánchez Rodríguez, L., \& Sáenz de Santa María, M. (1990). Curso de derecho internacional público. Vol. I. Madrid: Servicio de Publicaciones Universidad Complutense de Madrid.

Herdegen, M. (2005). Derecho internacional público. México D. F.: UNAM - Fundación Konrad Adenauer.

Jiménez de Aréchaga, E. (1962). Introducción al problema de las relaciones entre el derecho internacional y el derecho interno. En Separata de la Revista Jurídica de Buenos Aires.

Kelsen, H. (1965a). Teoría pura del derecho. Buenos Aires: Eudeba.

Kelsen, H. (1965b). Principios de derecho internacional público. Buenos Aires: El Ateneo.

Llanos Mansilla, H. (1990). Teoría y práctica del derecho internacional público. Tomo I. Santiago: Jurídica de Chile.

Loayza Tamayo, C. (2007). Los tratados de derechos humanos en el marco del derecho internacional y su interacción con el derecho interno peruano. En Justicia y reparación para mujeres víctimas de violencia sexual en contextos de conflicto armado interno. Lima: Consejería en Proyectos (PCS). Recuperado de http://www.observatorioviolencia.org/upload_images/File/DOC1192610621_justicia_ ViolSexual_PCS.pdf

Maureira Santis, N. T. (s. f.). Las normas ius cogens. Recuperado de http://congresoconstitucional.cl/wp-content/uploads/2010/08/ Ninoska-Maureira_1252889224.pdf

Medina, C. (1996). El derecho internacional de los derechos humanos. En Medina, C. \& Mera, J. (Eds.). Sistema jurídico y derechos humanos. Santiago: Sociedad de Ediciones Universidad Diego Portales. 
Miaja de la Muela, A. (setiembre-diciembre de 1974). La primacía sobre los ordenamientos jurídicos internos del derecho internacional y del derecho comunitario europeo. Revista de Instituciones Europeas, 1.

Monroy Cabra, M. G. (1978). Derecho de los tratados. Bogotá: Temis.

Nieto Navia, R. (junio de 1977). El derecho imperativo (jus cogens) en el derecho internacional a la luz de la Convención de Viena de 1969. Universitas Ciencias Jurídicas y Socioeconómicas, 52. Bogotá: Pontificia Universidad Javeriana.

Novak, F. (julio-diciembre de 1994). Los tratados y la Constitución peruana de 1993. Agenda Internacional, año I, 2. Lima: Pontificia Universidad Católica del Perú, Instituto de Estudios Internacionales.

Novak, F. (2000). Derecho internacional público. Tomo I. Lima: Pontificia Universidad Católica del Perú, Fondo Editorial.

Novak, F., \& Salmón, E. (2000). Las obligaciones internacionales del Perú en materia de derechos humanos. Lima: Pontificia Universidad Católica del Perú, Fondo Editorial.

ONU. Documento ONU A/CONF.39/11.

Pastor Ridruejo, J. A. (1962). La jurisprudencia del Tribunal Internacional de La Haya (sistematización y comentarios). Madrid: Rialp.

Piérola Balta, N. de, \& Loayza, C. (1994). Las Constituciones de 1989 y 1993 frente al derecho internacional. En Casos y textos de derecho internacional. Materiales de enseñanza. Lima: Universidad de Lima.

Piza Escalante, R. (1998). El valor del derecho y la jurisprudencia internacionales de derechos humanos en el derecho y la justicia internos. El ejemplo de Costa Rica. En Liber Amicorum Héctor Fix-Zamudio. Volumen I. San José de Costa Rica: Corte Interamericana de Derechos Humanos.

Remiro Brotons, A. et al. (2007). Derecho internacional. Valencia: Tirant Lo Blanch.

Rodríguez Carrión, A. (2009). Lecciones de derecho internacional público. (6. ${ }^{\mathrm{a}}$ ed., 2. ${ }^{a}$ reimp.). Madrid: Tecnos.

Sánchez Flores, A. (2004). La cláusula democrática en el sistema interamericano como norma de soft law. Agenda Internacional, año XI, 21. Lima: Pontificia Universidad Católica del Perú, Instituto de Estudios Internacionales. 
Tribunal Constitucional del Perú. Expediente 047-2004-AI/TC. Sentencia del Pleno jurisdiccional de 24 de abril de 2006.

Universidad de Cádiz. (s. f.). Soft law y derecho de extranjería. Recuperado de http://www2.uca.es/grup-invest/sej-352/expert-UNIDAD_9_DE_MAYO_2005.pdf

Vallarta Marrón, J. L. (2010). La argumentación jurídica en torno al ius cogens internacional. Anuario Mexicano de Derecho Internacional, vol. 10. Recuperado de biblio.juridicas.unam.mx/estrev/pdf/ derint/cont/10/art/art1.pdf

Verdross, A. (1978). Derecho internacional público. Madrid: Aguilar. 